ORIGINAL RESEARCH ARTICLE

\title{
Influence of Knowledge of Spousal Fertility Cycles on Male Reproductive Health Participation in Ibadan Metropolis, Nigeria
}

\author{
Taiwo A. Obembe ${ }^{1,2^{*}}$, Kehinde O. Odebunmi ${ }^{3}$, Kayode O. Osungbade ${ }^{2}$ and Babatunde O. \\ Adedokun ${ }^{4}$
}

University of Witwatersrand, School of Public Health, Education Campus, Johannesburg, South Africa ; Department of Health Policy and Management, Faculty of Public Health, College of Medicine, University of Ibadan $^{2}$; Department of Hospice and Palliative Medicine, University College Hospital, Ibadan ${ }^{3}$; Department of Epidemiology and Medical Statistics, Faculty of Public Health, College of Medicine, University of Ibadan ${ }^{4}$

*For Correspondence: E-mail: tobems@yahoo.com; Phone: +234-805-840-9495

\begin{abstract}
Despite the established roles and influence of men on women's uptake and utilization of reproductive health care interventions, the degree of involvement with intimate issues within the household which could help to understand male involvement and support remains an under-researched topic. The aim of this study was to investigate the degree of involvement at the family level of men within sub-urban communities of Ibadan in South-West Nigeria. A cross sectional survey design was conducted among 380 men selected from sub-urban communities in Ibadan, Oyo State using multi-stage sampling. Data was obtained using pretested, semi-structured, interviewer administered questionnaires. Data were analysed using descriptive statistics, bivariate analysis and logistic regression with level of significance set at 5\%. Mean age of respondents was $41.1 \pm 7.6$ years. Men who were knowledgeable of spouse's menstrual cycles and ovulation dates were significantly more likely to have supported some form of public health intervention before $(\mathrm{p}<0.001)$. Age over 30 , above secondary education, and men aware of menstrual dates of spouse were significant predictors of reproductive health interventions. Men who were aware of menstrual cycles of spouse were $96.6 \%$ more likely to be supportive or involved in reproductive health matters compared to those who were not $(\mathrm{OR}=0.034$; $95 \% \mathrm{CI}=0.02-0.07 ; \mathrm{p}<0.001)$. Involvement of men at family level as demonstrated in this study serves to influence and explain the level of involvement with reproductive health. Further research investigating other proximal factors that influence male participation is recommended. (Afr J Reprod Health 2017; 21 [3]: 76-88).
\end{abstract}

Keywords: reproductive health, health disparities, male involvement, menstrual cycle, ovulatory cycles, fertility

\section{Résumé}

En dépit des rôles établis et de l'influence des hommes sur la prise en charge des femmes et l'utilisation des interventions en matière de soins de santé de la reproduction, le degré de participation aux problèmes intimes au sein du ménage qui pourrait aider à comprendre l'implication et le soutien des hommes demeure un sujet de recherche insuffisamment étudié. L'objectif de cette étude était d'étudier le degré d'implication au niveau familial des hommes dans les communautés sub-urbaines d'Ibadan dans le sud-ouest du Nigéria. Une étude transversale a été menée auprès de 380 hommes sélectionnés parmi les communautés suburbaines d'Ibadan, dans l'État d'Oyo, en utilisant un échantillonnage en plusieurs étapes. Les données ont été obtenues à l'aide de questionnaires pré-testés, semi-structurés et administres à partir des interviews. Les données ont été analysées en utilisant des statistiques descriptives, une analyse bivariée et une régression logistique avec un niveau de signification fixé à 5\%. L'âge moyen des répondants était de 41,1 \pm 7,6 ans. Les hommes qui connaissaient bien les cycles menstruels et les dates d'ovulation des épouses étaient beaucoup plus susceptibles d'avoir soutenu une forme d'intervention de santé publique avant ( $p<0,001)$. L'âge de plus de 30 ans, l'enseignement supérieur au niveau secondaire, et les hommes connaissance les dates menstruelles des épouses constituaient des indices significatifs des interventions de santé reproductive. Les hommes qui connaissaient les cycles menstruels de l'époux étaient 96,6\% plus susceptibles d'être favorables ou impliqués dans des problèmes de santé génésique par rapport à ceux qui n'étaient pas $(\mathrm{OR}=0,034 ; \mathrm{IC} 95 \%=0,02-0,07 ; \mathrm{p}<0,001)$. L'implication des hommes à l'échelle familiale, telle que démontrée dans cette étude, sert à influencer et à expliquer le niveau de participation à la santé de la reproduction. D'autres recherches sur d'autres facteurs proximaux qui influencent la participation des hommes sont recommandées. (Afr $J$ Reprod Health 2017; 21[3]: 76-88).

Mots clés: santé de la reproduction, disparités en matière de santé, implication masculine, cycle menstruel, cycles ovulatoires, fertilité 


\section{Introduction}

For several decades, health planners have mainly focused their studies on how the attitudes, knowledge and behavior of women can be adjusted especially with regards to reproduction, family planning, contraceptive use and fertility issues ${ }^{1}$. This initial drive was based on the obvious observation that women are responsible for the majority of processes involved with childbirth. However, as time went on, it became obvious that in some countries, studies and programs on reproductive health and behavior based solely on women were not delivering the desired results even after all key areas were attended to by the health planners. Further investigations revealed that in certain communities and countries at large, although women carry most of the physical and emotional strains of pregnancy, childbirth and child rearing, the men occupied critical roles in terms of decision making in most settings ${ }^{2}$. For instance, in India, it was reported that even though the women in Kerala were eligible to receive free contraception and were willing to do so, $40 \%$ of them did not use the contraception due to objection by their husbands ${ }^{1}$. In Nigeria and other parts of sub-Saharan Africa, males are recognized as the head of the household and are solely responsible for decision-making in most family oriented reproductive health issues ${ }^{3}$. This informed the decision of more studies to focus on the roles of men in determining the reproductive and fertility characteristics of their families.

In Nigeria, this need has taken on added importance as a result of the high household size reported in the country. The 2013 Nigeria Demographic and Health Survey (NDHS) puts the total fertility rate at 5.5, which is one of the highest in the world (even higher than the 5.05 in sub-Saharan Africa) ${ }^{4}$. This has largely stimulated studies on men from various standpoints. For instance, Oyediran and colleagues investigated the level of knowledge and use of contraceptive methods by Nigerian men ${ }^{5}$ while Wusu explored how the family structure and family size were dependent on the head of household characteristics ${ }^{6}$. Fertility desires have been investigated $^{7}$ while Sedgh and colleagues went further to investigate and explore the role men play in the occurrence of unplanned pregnancies ${ }^{8}$. Likewise, the evaluation of the knowledge of males for danger signs in pregnancy in Nigeria ${ }^{9}$ goes to further emphasize the role and importance of men in relevant public health issues and interventions. These studies also demonstrate the important roles men play in determining their partners' reproductive behaviours.

Even though studies have recognized the importance of determining the level of male involvement in women's lives at the family level in other patriarchal settings such as India and Papua New Guinea and in Nigeria ${ }^{10,11}$, the extent with regards to how involved males are with personal and reproductive issues of their spouses at the family level remains under-researched in Nigeria.. Exploring the degree of involvement by men at family and personal levels is important as it may actually serve as a proxy to understanding levels of support and involvement with public health outcomes. To the best of our knowledge, this is the first study that examines the degree of involvement at the family level. The study aims to answer the following questions: What is the extent of involvement of Nigerian men in their spouses' reproductive health? Is there any relationship between gender preference and the level of involvement of men in women's reproductive issues at the family level? This study expounds these issues by ascertaining the level of involvement of men in the fertility cycles of their partners as well as the factors associated with their involvement in women's lives at the family level.

\section{Methods}

\section{Study area}

Three hundred and eighty (380) residents were recruited from Ibadan, Oyo State, southwestern Nigeria using a cross sectional study. Nigeria is situated in West Africa with an estimated population size of $170,000,000$ and a total of 774 local government areas ${ }^{12}$. Oyo State lies within longitude $3.933^{\circ}$ East and latitude $7.85^{\circ}$ north. It has an approximate landmass of $28,246.264 \mathrm{~km}^{2}$ and a population of about $6,182,172^{13}$. At present, there are eleven local governments in Ibadan metropolitan area consisting of five urban areas 
(Ibadan North, Ibadan North-East, Ibadan NorthWest, Ibadan South-West, and Ibadan South East) and six sub-urban local governments in the city where the study was conducted ${ }^{14}$.

\section{Study population}

Study population comprised males participants aged $18-65$ years, recruited from sub-urban communities in Ibadan, who have resided for at least one year prior to the study.

\section{Sampling strategy}

Multistage sampling was used for selection of study participants. In the first stage, a sampling frame of all six local government areas of suburban Ibadan metropolitan area was obtained ${ }^{15}$ and one local government area was selected randomly by balloting. In stage 2 , a complete list of all the communities within the local government areas was obtained and 2 communities were selected from each local government using proportionate allocation based on the estimated sample size.

In stage 3, all enumeration areas in the selected communities were selected. Each enumeration area had 10-35 houses with about 6-10 adults per house. All eligible adults in each enumeration area were interviewed. Participants within the selected community who consented to participate in the study were recruited. Subsequently, every consecutive household were approached and fathers were interviewed in that manner according to how they gave consent.

Ethical approval for this study was sought and gotten from the University of Ibadan/University College Hospital Institutional Review Committee before study was initiated. Written informed consent was also obtained from participants before administering questionnaires. Proper community entry was later observed by obtaining approval from the appropriate community leaders. The study was thoroughly explained to participants before consent to participate in the study was obtained. A total of 380 men were selected to participate in the study determined using the formula: $n=N^{2} p(1-p) / N^{2}$ $+Z^{2} p(1-p)$.

Data were collected between August 2014 and December 2014 by trained research assistants with semi-structured interviewer administered questionnaires, designed based on the study objectives. The questionnaire was initially pretested in a community which was similar in characteristics with the proposed study site. Ambiguities were corrected after which it was subjected to measures of internal consistency with the use of Cronbach's Alpha test to check the reliability of the survey instrument before final administration. A Cronbach alpha score of 0.87 was obtained that showed good internal consistency of our study instrument.

Independent variables included the sociodemographic characteristics, number of children, category of children (either male only, female only or mixed) while dependent variables included knowledge of spouse's menstrual cycle dates and ovulation day. For knowledge of menstrual cycle dates, responses were coded as "I am sure of her dates' $=1$; "I used to know but can't remember now $=2$; "never bothered to find out $=3$ ". For participants that answered "I used to know but can't remember now $=2$; "never bothered to find out=3", responses were re-grouped into, "No I don't know". While for ovulation dates, responses were coded as, "Yes=1"; "No=2". Ethnicity was later re-classified as "Yoruba $=1$ and others $=2$ " while marital status was also re-grouped into, "Married=1 and others=2".

Data from the field was entered into Stata software (version 20) and checked for double entry by independent entry clerks for quality control. Categorical variables were presented as proportions while continuous variables were summarized as means and standard deviation (for uniformly distributed data) or as median and range (for data that is not normally distributed). Chi square test was used to test for associations of categorical variables with binary outcomes. Fisher's exact were used to test for associations with variables less than 5 in any of its cells. Multiple logistic regression analysis was done to 
Table 1: Socio-Demographic Characteristics of Respondents

\begin{tabular}{|c|c|c|}
\hline & $\begin{array}{l}\text { Frequency } \\
\text { (N) }\end{array}$ & $\begin{array}{l}\text { Percentage } \\
(\%)\end{array}$ \\
\hline \multicolumn{3}{|l|}{ Age group $(\mathrm{N}=380)$} \\
\hline$<30 \mathrm{yrs}$ & 21 & 5.5 \\
\hline $30-39$ years & 155 & 40.8 \\
\hline $40-49$ years & 162 & 42.6 \\
\hline$\geq 50$ years & 42 & 11.1 \\
\hline \multicolumn{3}{|l|}{ Mean(SD) $40.9 \pm 7.6$} \\
\hline \multicolumn{3}{|l|}{ Occupation $(\mathrm{N}=380)$} \\
\hline Civil Servants & 177 & 46.6 \\
\hline Traders & 24 & 6.3 \\
\hline Artisans & 53 & 13.9 \\
\hline Farmers & 72 & 18.9 \\
\hline Others* & 54 & 14.2 \\
\hline \multicolumn{3}{|l|}{ Ethnicity (N=380) } \\
\hline Yoruba & 211 & 55.5 \\
\hline Hausa & 88 & 23.2 \\
\hline Igbo & 68 & 17.9 \\
\hline Otherst & 13 & 3.4 \\
\hline \multicolumn{3}{|l|}{ Religion (N=380) } \\
\hline Islam & 117 & 30.8 \\
\hline Christianity & 227 & 59.7 \\
\hline Traditional & 36 & 9.5 \\
\hline \multicolumn{3}{|l|}{ Marital Status (N=380) } \\
\hline Married & 310 & 81.6 \\
\hline Separated & 15 & 3.9 \\
\hline Divorced & 14 & 3.7 \\
\hline Common Law Partner & 41 & 10.8 \\
\hline \multicolumn{3}{|l|}{ Highest Educational } \\
\hline \multicolumn{3}{|l|}{ Level $(N=380)$} \\
\hline No Formal Education & 46 & 12.1 \\
\hline Primary Education & 49 & 12.9 \\
\hline Secondary Education & 81 & 21.3 \\
\hline Tertiary Education & 131 & 34.5 \\
\hline Post Graduate & 63 & 16.6 \\
\hline Tech/Professional & 10 & 2.6 \\
\hline \multicolumn{3}{|l|}{$\begin{array}{l}\text { Number of Children } \\
(\mathrm{N}=380)\end{array}$} \\
\hline$\leq 2$ & 127 & 33.4 \\
\hline $3-4$ & 147 & 38.7 \\
\hline$\geq 5$ & 106 & 27.9 \\
\hline \multicolumn{3}{|l|}{$\begin{array}{l}\text { Category of child } \\
(\mathrm{N}=380)\end{array}$} \\
\hline Male Only & 112 & 29.5 \\
\hline Female Only & 232 & 61.1 \\
\hline Both Sexes & 36 & 9.5 \\
\hline
\end{tabular}

*Others: Bricklayers, Security men, Students, Bankers, Unemployed, Healthcare personnel

†Others: Hausa, Igbo, Efik, Ibibio, Tiv

determine the adjusted odds of knowledge of spouse's menstrual cycle dates and ovulation day. Results were reported at level of statistical significance set at $5 \%$.

\section{Results}

\section{Socio-demographic characteristics}

A total of 380 questionnaires out of 410 questionnaires were returned, giving a response rate of $92.7 \%$. Mean age of respondents was 41.1 \pm 7.6 years while the ages ranged from 22 years to 63 years with the highest proportion in the 40-49 years age group (42.6\%). Almost half (46.6\%) of the respondents were civil servants followed by farmers (18.9\%), traders (5.8\%) and artisans $(13.5 \%)$. The majority of the respondents $(55.7 \%)$ were of Yoruba descent. Almost three out of every five respondents $(59.7 \%)$ were of the Christian faith, $30.8 \%$ were Muslims, and $9.5 \%$ were traditionalists. The married respondents constituted a vast majority $(81.6 \%)$, while about one-tenth $(10.8 \%)$ of them were involved in common law partnerships. Respondents that had completed tertiary education accounted for the largest proportion of our respondents (34.5\%), followed by those that completed secondary education $(21.3 \%)$. Only $16.6 \%$ had completed some postgraduate training. About a third of respondents $(33.4 \%)$ had less than 2 children and men with female-only children constituted $61.1 \%$ of respondents (Table 1).

\section{Male involvement and factors associated with male involvement in spouse's menstrual and ovulatory cycles}

When asked of their spouse's menstrual cycles, just about one-quarter $(25.5 \%)$ of them were affirmative of the exact dates of the menstrual dates of their partners. A breakdown of these figures by age group among those that were affirmative showed that 30-39 year age group had the highest proportion $(47.4 \%)$ compared to those less than 30 years $(4.1 \%), 40-49$ years $(37.2 \%)$ and over 50years $(11.3 \%)$ - a difference that was not statistically significant $(\mathrm{p}=0.438)$ Other occupations $(53.6 \%)$; participants that had completed secondary education $(48.5 \%)$; Yoruba ethnicity $(51.5 \%)$, married men $(86.6 \%)$, could correctly recount the menstrual dates for their spouses more compared to their counterparts. 
Table 2: Association between Socio-Demographic Characteristics and Male Involvement in Spousal Menstrual Cycle Dates

\begin{tabular}{|c|c|c|c|c|c|}
\hline & \multirow[b]{2}{*}{ Age group } & \multicolumn{3}{|c|}{ Do you know/follow your wife/partner's menstrual cycle dates } & \multirow[b]{2}{*}{ P-value } \\
\hline 1. & & $\begin{array}{l}\text { I am sure of her } \\
\text { dates } \\
(n=97)\end{array}$ & $\begin{array}{l}\text { I am not sure of her } \\
\text { dates } \\
(n=283)\end{array}$ & Chi Square & \\
\hline & $<30$ years & $4(4.1 \%)$ & $17(6.0 \%)$ & 2.694 & $.438 \S$ \\
\hline & $30-39$ years & $46(47.4 \%)$ & $109(38.5 \%)$ & & \\
\hline & $40-49$ years & $36(37.2 \%)$ & $126(44.5 \%)$ & & \\
\hline & $\geq 50$ years & $11(11.3 \%)$ & $31(11.0 \%)$ & & \\
\hline \multirow[t]{3}{*}{2.} & Occupation & & & & \\
\hline & Civil Servants & $45(46.4 \%)$ & $132(46.6 \%)$ & .002 & .966 \\
\hline & Others* & $52(53.6 \%)$ & $151(53.4 \%)$ & & \\
\hline \multirow[t]{4}{*}{3.} & Educational Status & & & & \\
\hline & No Education & $11(11.3 \%)$ & $35(12.4 \%)$ & 635 & .748 \\
\hline & $\begin{array}{l}\text { Professional \& Primary } \\
\text { Education }\end{array}$ & $39(40.2 \%)$ & $101(35.7 \%)$ & & \\
\hline & $\begin{array}{l}\text { Secondary education \& } \\
\text { above }\end{array}$ & $47(48.5 \%)$ & $147(51.9 \%)$ & & \\
\hline \multirow[t]{3}{*}{4.} & Ethnic Group & & & & \\
\hline & Yoruba & $50(51.5 \%)$ & $161(5.7 \%)$ & .835 & .361 \\
\hline & Others & $47(48.5 \%)$ & $122(94.3 \%)$ & & \\
\hline \multirow[t]{3}{*}{5.} & Marital Status & & & & \\
\hline & Married & $84(86.6 \%)$ & $226(79.9 \%)$ & 2.183 & .140 \\
\hline & Others $¥$ & $13(13.4 \%)$ & $57(20.1 \%)$ & & \\
\hline \multirow[t]{3}{*}{6.} & Religion & & & & \\
\hline & Christianity & $50(51.5 \%)$ & $177(62.5 \%)$ & 3.633 & .057 \\
\hline & Others\# & $47(48.5 \%)$ & $106(37.5 \%)$ & & \\
\hline \multirow[t]{4}{*}{7.} & $\begin{array}{l}\text { How many children do } \\
\text { you have now? }\end{array}$ & & & & \\
\hline & $\leq 2$ & $30(30.9 \%)$ & $97(34.3 \%)$ & 1.682 & .431 \\
\hline & $3-4$ & $35(36.1 \%)$ & $112(39.6 \%)$ & & \\
\hline & $\geq 5$ & $32(33.0 \%)$ & $74(26.1 \%)$ & & \\
\hline \multirow[t]{4}{*}{8.} & Category of Child & & & & \\
\hline & Male only & $31(32.0 \%)$ & $81(28.6 \%)$ & 1.156 & .561 \\
\hline & Female only & $55(56.7 \%)$ & $177(62.6 \%)$ & & \\
\hline & Both & $11(11.3 \%)$ & $25(8.8 \%)$ & & \\
\hline \multirow[t]{3}{*}{9.} & $\begin{array}{l}\text { Do you want more } \\
\text { children? }\end{array}$ & & & & \\
\hline & Yes & $70(72.2 \%)$ & $185(65.4 \%)$ & 1.511 & .219 \\
\hline & No & $27(27.8 \%)$ & $98(34.6 \%)$ & & \\
\hline
\end{tabular}

*Others: Traders, Artisans, farmers, Bricklayers, Security men, Students, Bead makers, Unemployed

$\$$ Others: Hausa, Igbo, Efik. Ibibio, Tiv

$¥$ Others: Single, separated, divorced, widowed

\#Others: Islam, Traditional

$\S$ Fishers' Exact

These findings were however not significant $(\mathrm{p}=$ $0.966 ; \mathrm{p}=0.748 ; \mathrm{p}=0.361 ; \mathrm{p}=0.140$ respectively). The effect of religion on whether men follow spousal dates was found to be marginally nonsignificant as more Christians (51.5\%) compared to other religions $(48.5 \%)$ could accurately tell the menstrual dates for their spouses $(p=0.057)$. With regards to the 'number of children' and the 'category of children', more men with 3-4 children
$(36.1 \%)$ and men with female-only children $(56.7 \%)$ could accurately recount the menstrual dates compared to others. These were also however non-significant findings $(\mathrm{p}=0.431$ and $\mathrm{p}=0.561$ respectively). Lastly, men who desired more children $(72.2 \%)$ were more attentive to the dates of their spouses compared to those who had completed their family sizes $(\mathrm{p}=0.219)$ (Table 2). 
Table 3: Association between Socio-Demographic Characteristics and Male Knowledge of Spousal Ovulation Dates

\begin{tabular}{|c|c|c|c|c|c|}
\hline & \multicolumn{3}{|c|}{ Are you aware/sure of your wife/partner's ovulation day } & \multirow[b]{2}{*}{ Chi Square } & \multirow[b]{2}{*}{ P-Value } \\
\hline & & $\begin{array}{l}\text { Yes } \\
\mathbf{N}(\%)\end{array}$ & $\begin{array}{l}\text { No } \\
\text { N }(\%)\end{array}$ & & \\
\hline \multirow[t]{5}{*}{1.} & Age Group & & & & \\
\hline & $<30$ years & $6(7.5)$ & $15(5.0)$ & 3.047 & 0.384 \\
\hline & $30-39$ years & $35(43.7)$ & $120(40.0)$ & & \\
\hline & $40-49$ years & $34(42.5)$ & $128(42.7)$ & & \\
\hline & $\geq 50$ years & $5(6.3)$ & $37(12.3)$ & & \\
\hline \multirow[t]{3}{*}{2.} & Occupation & & & & \\
\hline & Civil Servants & $43(53.7)$ & $134(44.7)$ & 2.094 & .148 \\
\hline & Others* & $37(46.3)$ & $166(55.3)$ & & \\
\hline \multirow[t]{3}{*}{3.} & Ethnic Group & & & & \\
\hline & Yoruba & $43(53.7)$ & $168(56.0)$ & .129 & .719 \\
\hline & Others $\ddagger$ & $37(46.3)$ & $132(44.0)$ & & \\
\hline \multirow[t]{3}{*}{4.} & Religion & & & & \\
\hline & Christianity & $45(56.3)$ & $182(60.7)$ & .512 & .522 \\
\hline & Others \# & $35(43.7)$ & $118(39.3)$ & & \\
\hline \multirow[t]{3}{*}{5.} & Marital Status & & & & \\
\hline & Married & $65(81.3)$ & $245(81.7)$ & .007 & .932 \\
\hline & Others $¥$ & $15(18.7)$ & $55(18.3)$ & & \\
\hline \multirow[t]{5}{*}{6} & Educational Status & & & & \\
\hline & No Education & $9(11.2)$ & $37(12.3)$ & 633 & .729 \\
\hline & Professional & $27(33.8)$ & $113(37.7)$ & & \\
\hline & Primary Education & & & & \\
\hline & $\begin{array}{l}\text { Secondary Education } \\
\& \text { above }\end{array}$ & $44(55.0)$ & $150(50.0)$ & & \\
\hline \multirow[t]{4}{*}{7.} & How many children do & you have I & & & \\
\hline & $\leq 2$ & $29(36.3)$ & $98(32.7)$ & 0.547 & 0.761 \\
\hline & $\overline{3}-4$ & $31(38.7)$ & $116(38.7)$ & & \\
\hline & $\geq 5$ & $20(25.0)$ & $86(28.6)$ & & \\
\hline \multirow[t]{4}{*}{8.} & Category of Child & & & & \\
\hline & Male only & $28(35.0)$ & $84(28.0)$ & 2.273 & 0.321 \\
\hline & Female only & $43(53.8)$ & $189(63.0)$ & & \\
\hline & Both & $9(11.2)$ & $27(9.0)$ & & \\
\hline \multirow[t]{3}{*}{9.} & Do you want more chil & Iren & & & \\
\hline & Yes & $51(63.7)$ & $204(68.0)$ & .517 & .472 \\
\hline & No & $29(36.3)$ & $96(32.0)$ & & \\
\hline
\end{tabular}

*Others: Traders, Artisans, farmers, Bricklayers, Security men, Students, Bead makers, Unemployed

\$ Others: Hausa, Igbo, Efik. Ibibio, Tiv

¥Others: Single, separated, divorced, widowed

\#Others: Islam, Traditional

\section{Awareness of ovulatory phases of spouse}

With regard to their partners' ovulatory cycles, only $80(21.1 \%)$ of the respondents knew the exact days their partners were ovulating. Age group 3039 years $(43.7 \%)$ were most attentive to the ovulatory cycles of their spouses compared to the other age groups $(\mathrm{p}=0.384)$. Civil servants $(53.7 \%)$ paid more attention to ovulatory cycles of their spouses compared to others $(\mathrm{p}=0.148)$, while Yorubas $(53.7 \%)$ more than other ethnicities (46.3\%) paid more attention to the spouses' ovulatory cycles $(\mathrm{p}=0.719)$. Likewise, Christians $(56.3 \%)$, married men $(81.3 \%)$ and respondents who had at least secondary education (55.0\%) were more attentive to ovulatory cycles of their spouses compared to their counterparts $(\mathrm{p}=0.522$; $\mathrm{p}=0.932$ and $\mathrm{p}=0.729$ respectively). Men with family size of between 3-4 children (38.7\%); men with female only children (53.8\%); and men who were interested in more children paid also more attention to the ovulatory cycles of their spouses more than their counterparts $(\mathrm{p}=0.761 ; \mathrm{p}=0.321$; $\mathrm{p}=0.472$ respectively) (Table 3 ). 
Table 4: Test of Men's Knowledge of Ovulation in Spouse

\begin{tabular}{|c|c|c|c|}
\hline \multirow[t]{2}{*}{$\mathrm{S} / \mathrm{N}$} & \multicolumn{3}{|l|}{ Men's Knowledge of Ovulations Signs } \\
\hline & & Frequency $(\mathrm{N})$ & Percent (\%) \\
\hline \multirow[t]{6}{*}{1} & Ovulation signs looked for $(\mathrm{n}=80)$ & & \\
\hline & Basal Body Temperature & 19 & 23.8 \\
\hline & Increased libido of spouse & 24 & 30.0 \\
\hline & Pimples & 11 & 13.8 \\
\hline & Others & 26 & 32.5 \\
\hline & Total & 80 & 100.0 \\
\hline \multirow[t]{7}{*}{2} & Ovulation period as perceived by respondent $(n=80)$ & & \\
\hline & During her menses & 5 & 6.2 \\
\hline & 1st week after menses & 21 & 26.3 \\
\hline & Mid-cycle & 24 & 30.0 \\
\hline & Last week before the next menses & 12 & 15.0 \\
\hline & I don’t know & 18 & 22.5 \\
\hline & Total & 80 & 100.0 \\
\hline \multirow[t]{4}{*}{3} & $\begin{array}{l}\text { Makes a conscious effort to have sexual intercourse with spouse during her } \\
\text { ovulation }\end{array}$ & & \\
\hline & Yes & 59 & 73.7 \\
\hline & No & 21 & 26.3 \\
\hline & Total & 80 & 100.0 \\
\hline
\end{tabular}

Others: Abdominal cramps mid-cycle, salty sweat, ovulation kit, breast tenderness

Test of men's knowledge of ovulation in spouse

An increase in libido of the spouse was the most explored sign that men from sub-urban communities used to predict the ovulatory phase of their spouses $(30.0 \%)$ followed closely by an increase in basal body temperature (23.8\%). Interestingly, most men correctly identified the ovulation of their spouses to occur at mid-cycle $(30.0 \%)$ followed by those who believed it occurred in the $1^{\text {st }}$ week after menstruation $(26.3 \%)$. A good proportion of respondents (22.5\%) also admitted total lack of knowledge as to when this occurs. Of those that admitted to knowing the time of the month when their spouses are ovulating, $73.7 \%$ put in some effort to be with spouses at this time (Table 4).

\section{Attendance/involvement with reproductive health-related issue}

More respondents between age groups of 30-39 years (42.7\%); other occupations (51.6\%); Christians (54.8\%); married men (81.5\%); educational status attainment of at least secondary education (52.4\%); men with 3-4 children (37.1\%) compared to their counterparts had been more involved in health matters regarding the family or spouse before. These findings were equally not significant $(\mathrm{p}=0.384 ; \mathrm{p}=0.623 ; \mathrm{p}=0.175 ; \mathrm{p}=0.964$, $\mathrm{p}=0.120$ and $\mathrm{p}=0.898$ respectively). More Yorubas (58.2\%) compared to other ethnicities had not been involved nor had accompanied their spouses for any health related matter before $(p=0.131)$. Respondents with female only children $(51.6 \%)$; respondents with lack of awareness of spousal ovulatory cycles/dates (62.1\%); and men that were knowledgeable of spouses' menstrual dates $(64.5 \%)$ were found to have accompanied their spouses for reproductive health related event before $(\mathrm{p}=0.026 ; \mathrm{p}<0.001 ; \mathrm{p}<0.001$ respectively) (Table 5).

\section{Predictors of involvement and support of reproductive health issues}

Age less than 30 years $(\mathrm{p}=0.046)$, professional training or at least primary education $(\mathrm{p}=0.039$, men that follow menstrual dates $(\mathrm{p}<0.001)$ of spouses were all significant predictors of involvement in a health issues (Table 6). Respondents aged 30years and below had 76.4\% lower odds to be involved in a health related matter compared to those aged 50 and above $(\mathrm{OR}=0.24 ; \quad \mathrm{CI}=0.06-0.98)$. Those with professional and primary education had about $71.8 \%$ lower odds of an involvement with a health 
Table 5: Association between Socio-Demographic Characteristics and Involvement with Reproductive Health Issues

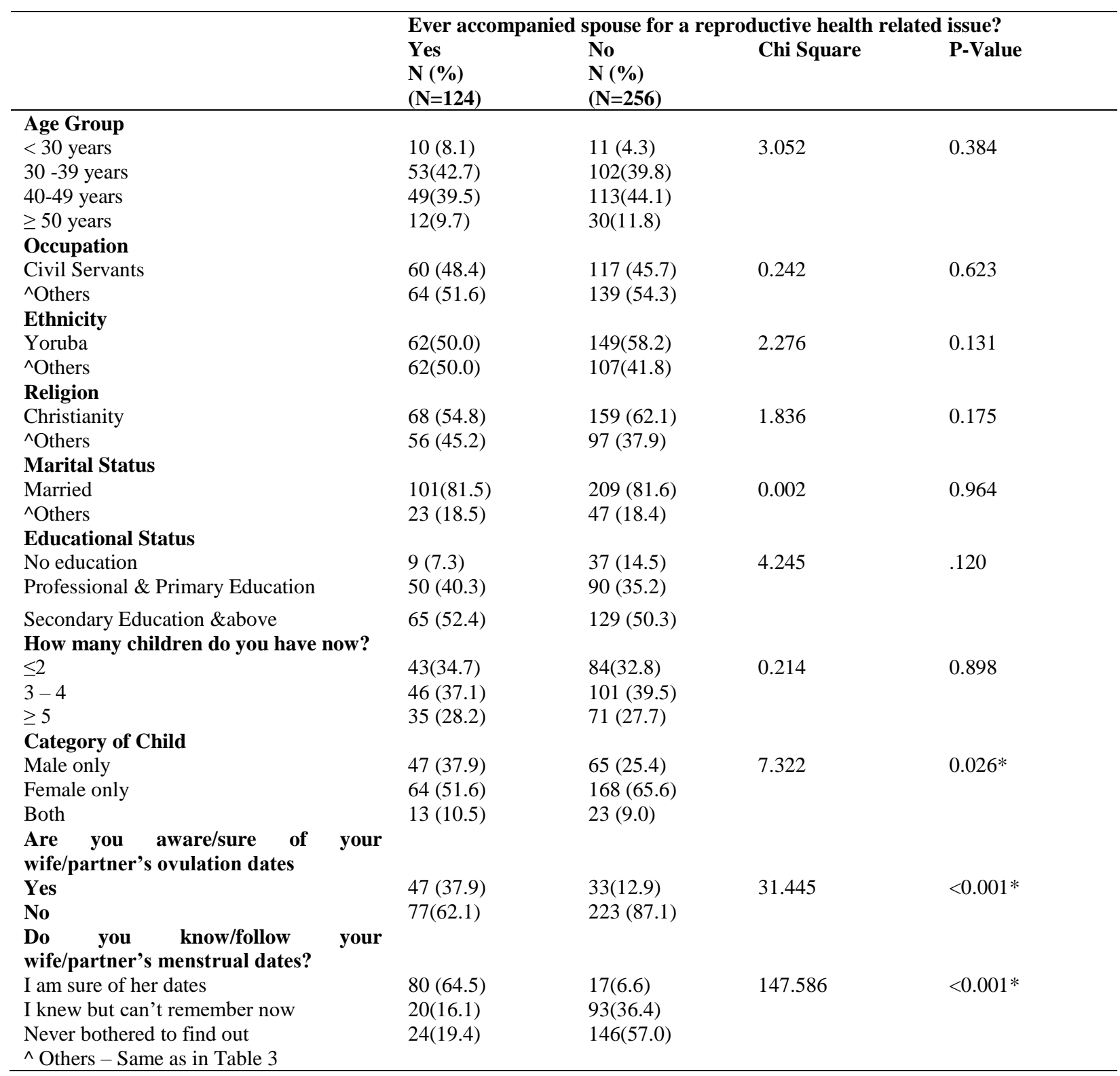

*Significant Associations

related matters compared to those without any form of education at all $(\mathrm{OR}=0.28 ; \mathrm{CI}=0.09-$ 0.94) (Table 6).

\section{Discussion}

The mean age of respondents $(40.9 \pm 7.6)$ observed in this study is similar to that reported in other studies in Nigeria ${ }^{1,16}$. This is likely the case because the demographic profile of the country has been found to be similar across all regions. In addition, studies involving men of reproductive age have reported similar results possibly an indication that the 30-49 year bracket represent the most active part of male reproductive years. The literacy rate of $87.3 \%$ observed in this study is relatively high when compared to the $70.5 \%$ male literacy rate at the national level ${ }^{4}$. When compared 
Table 6: Logistic Regression Predicting Participation in Reproductive Health Related Issues

\begin{tabular}{|c|c|c|c|c|}
\hline & Odds Ratio & $\begin{array}{l}95 \% \mathrm{CI} \\
\text { Lower }\end{array}$ & Upper & Sign. \\
\hline \multicolumn{5}{|l|}{ Age Group } \\
\hline Age $<30$ & .236 & .057 & .976 & $.046 *$ \\
\hline $30-39$ & .878 & .313 & 2.462 & .805 \\
\hline $40-49$ & .751 & .269 & 2.102 & .586 \\
\hline$>50$ yrs. & 1 & & & \\
\hline \multicolumn{5}{|l|}{ Occupation } \\
\hline (Civil servants & 1.165 & .621 & 2.186 & .634 \\
\hline Others & 1 & & & \\
\hline \multicolumn{5}{|l|}{ Number of Children } \\
\hline$>2$ & .900 & .343 & 2.363 & .830 \\
\hline $3-4$ & .838 & .354 & 1.982 & .687 \\
\hline$>5$ & 1 & & & \\
\hline \multicolumn{5}{|l|}{ Religion } \\
\hline Christianity & 1.083 & .537 & 2.183 & .825 \\
\hline Others & 1 & & & \\
\hline \multicolumn{5}{|l|}{ Marital Status } \\
\hline Married & 1.380 & .663 & 2.874 & .389 \\
\hline Others & 1 & & & \\
\hline \multicolumn{5}{|l|}{ Educational Status } \\
\hline No education & 1 & & & \\
\hline Professional \& Primary Education & .282 & .085 & .941 & $.039 *$ \\
\hline Secondary Education \& above & .297 & .089 & .998 & $.050 *$ \\
\hline \multicolumn{5}{|l|}{ Sex Category of Children } \\
\hline Male only & .651 & .209 & 2.024 & .458 \\
\hline Female only & 1.388 & .467 & 4.119 & .555 \\
\hline Both sexes & 1 & & & \\
\hline \multicolumn{5}{|l|}{ Ethnicity } \\
\hline Yoruba & 1.119 & .577 & 2.171 & .740 \\
\hline Others & 1 & & & \\
\hline \multicolumn{5}{|l|}{ Want more children } \\
\hline Yes & .696 & .359 & 1.348 & .282 \\
\hline No & 1 & & & \\
\hline \multicolumn{5}{|c|}{ Follows wife/partner's menstrual dates } \\
\hline Yes & .034 & .016 & .069 & $<0.001 *$ \\
\hline No & 1 & & & \\
\hline \multicolumn{5}{|c|}{$\begin{array}{l}\text { Follow or aware of wife/partner's ovulation } \\
\text { dates }\end{array}$} \\
\hline Yes & .729 & .348 & 1.526 & .402 \\
\hline No & 1 & & & \\
\hline Constant & .001 & 21.164 & & \\
\hline
\end{tabular}

*significant

to other studies in other regions of the country, this figure is high. NDHS (2013) places the range of male literacy levels of other geo-political zones between $93.9 \%$ and $47.9 \%$ with only the SouthSouth zone having a higher male literacy rate than the South West. This supports the theory that the Southwest region mainly inhabited by the Yorubas is one of the most educated regions in the country. This high literacy rate especially among the study participants can be rationally explained by government's efforts at implementing the free universal basic education ${ }^{17,18}$. Even though, universal basic education only supports primary education, the drive required to attain tertiary levels $(34.5 \%)$ of education may well have been established with the implementation of the universal basic education program. Interestingly also, a good proportion of our participants were 
civil servants that lived in the sub-urban communities. This could be a pointer to the reality of urban growth - a logical perspective as to the prevalence of civil servants still resident in the sub-urban communities. According to literature, current rate of urbanisation in Nigeria is estimated at 5.5percent per annum with over 61.1 percent of 167million Nigerians (an equivalent of 102.203 million) already residing in sub-urban communities as of $2012^{19}-\mathrm{a}$ situation that calls for active policy response by the policy makers and governmental authorities. Oyeleye argues for policies that favour reduction in fertility as an appropriate policy response to the effects of uncontrolled urbanization ${ }^{20}$.

The mean number of children reported in this study, 3.47 is quite lower than the 5.6 national fertility rate ${ }^{4}$. After splitting the respondents into various educational groups, it was discovered that there was a reduction in the average number of children as educational level completed increased. This concurs with earlier studies linking educational status of either male or female partner to the number of children they have. For instance, Osili and Long found that female education was associated with lower fertility rates ${ }^{21}$. Also, Bongaarts argued that men with higher education tend to have fewer number of children ${ }^{22}$ thus highlighting the importance of education to predict household size.

Men aged 30-39 years, showed the greatest interest in involvement with partners' menstrual cycles. This may be due to the fact that the younger age group (<30years) are probably single and as such not concerned with issues regarding fertility talk less menstrual cycle of their partners $^{23}$. The reason older age groups show increasing knowledge of their spouses' menstrual cycle dates may be due to the fact that they are probably married and had spent a longer amount of time together with their partners as opposed to the younger ones. In a mixed methods study, younger men were mostly concerned with just getting their partners pregnant and paid less attention to other details about their partners, especially when it pertained to reproductive and sexual health of their partners ${ }^{11}$. To further buttress this, improved levels of spousal communication have been reported in studies where the majority of the male respondents belong to higher age groups $^{24,25}$. This study also found that Yorubas had the highest proportion of men who knew exact menstrual cycle dates of their wives (Table 2). The polygamous nature commonly found with the Yorubas and Hausa clans could be barriers for intimate communication between husbands and wives $^{26}$. Furthermore, an infamous notion by husbands thinking that discussions around family planning and female reproductive health with wives is a dent on their manhood ${ }^{27}$ may also be a plausible reason for this lackadaisical attitude. Even though we did not collect information on polygamy, higher rates of polygamous unions may be responsible for the observed lower proportions of men being aware of their wives' cycle dates among the other tribes. Educational status was found in this study to be highly associated with knowledge of menstrual cycle dates as those with postgraduate education had the highest proportion of men who knew menstruation dates of their partners, while those who completed technical education had the least. Higher knowledge of menstrual cycle dates noticed in men who had completed postgraduate education corroborates literature that affirms a link between educational status and improved reproductive and sexual health factors, Divo and Afework showed that men who were more educated sought to initiate discussions about family planning with their wives $^{28}$. On the same note, males with higher education were more knowledgeable about natural family planning methods ${ }^{11}$, which relies heavily on knowledge of their partner's menstrual cycle.

Respondents' knowledge of partners' ovulation days did not quite follow the same trend as that of the menstrual cycle. The higher interest of the younger age groups in the ovulation dates of their partners may indicate that they are more interested in timing the births of their children and in controlling their family size. On the flip side, middle and older age groups probably paid less attention due to dwindling interest in having more children. Further studies have also discovered that the desire to give birth to more children produced a curvilinear graph when plotted with middle age groups desiring more children compared to other 
ages $^{29,30}$. The trend with respect to educational level completed with regards to ovulation, though, did not differ much from that of the knowledge of menstrual cycle dates nevertheless; respondents who had completed the government's prescribed years of basic education had a higher proportion of men who knew the exact days of their partner's ovulation. Once again, the importance of the link between educational status and the attitudes and behavior of males to reproductive health issues is brought to the fore. This had earlier being validated by Dunson and colleagues that established in their study a deeper involvement of more educated men with issues concerning the fertility and reproductive health of their partners $^{31,32}$. A significant association between higher education levels of men and attendance at antenatal care (ANC) or reproductive health care services has been established ${ }^{33,34}$ for which our study corroborates further. Communication between partners was also shown to be higher among the more educated men ${ }^{35}$. All of these indicate that education plays an important role in determining how involved a man is in his partner's reproductive health. The results also indicate that higher number of children was observed among those who had lower knowledge of their partners' ovulation dates. Notably, males who were interested in their spouse's sexual health had lower household sizes than their counterparts ${ }^{36,37}$. Although the difference is not statistically significant in this study, linking it with results from other studies, points to a likely association between knowledge of a partner's sexual health, controlled household sizes as well as practice of family planning - important statistics that demand due consideration when formulating reproductive health interventions or family planning and family spacing control policies. Jayalakshmi and colleagues in their study in India reported that although about $50 \%$ of their male respondents had knowledge of their partners' safe period, majority of them decided to have more than 3 children with the desire for sons as a primary factor ${ }^{10}$. However, in other settings, it was noticed that men in resource-poor settings do not have sufficient knowledge of the female reproductive cycle ${ }^{38}$. As such, a possible reason for the contradiction in results may be associated with the poor education men have on the link between knowledge of their partners' menstrual and ovulation cycle and the conception process. It is likely that men in this study do not pay attention to such matters whether they have male children or not due to their ignorance of its importance to childbirth.

Our study however had some limitations. The choice of our study design being a crosssectional study translated to the fact that causal relationships between explanatory and outcome variables could not be substantiated. Furthermore, the potential for recall bias is very important in this study as most of our questions had to do with recalling of dates. The cross-verification of dates quoted by our participants with their spouses would have been helpful to curtail this limitation. Readers should to be reminded that the results that demonstrate a high significance with regards to ethnicity could be as a result that the study was conducted in south-western Nigeria that is known to be inhabited primarily by the Yorubas. Lastly, the possibility of socially acceptable responses is very possible during the data collection process since our data was collected with the assistance of interviewers. Nevertheless, our study is the first (providing baseline statistics) that explains male involvement with reproductive health matters using more proximal family-oriented factors.

\section{Conclusion}

The significant association between men who were knowledgeable of spouse's menstrual dates and involvement in reproductive health issues calls for a need for campaigns that encourage more male involvement. Policies that transcend conventional norms, examining other important spheres of relationships that ultimately determine male involvement with reproductive health issues are urgently advocated particularly in low-income settings.

Even though the revised National Health Policy recognizes the need for a scale up of male involvement in reproductive issues ${ }^{39}$, salient facts such as educational status, knowledge of menstrual 
and ovulatory dates can further serve as veritable guides to draft feasible implementation work-plans as far as men are concerned.

\section{Authors' Contributions}

Author TAO conceptualized the study, drafted the study protocol and obtained ethical approval to execute the study. Authors KOOD supervised the data collection process. Authors BOA and TAO carried out the data analysis. Author TAO wrote the initial draft manuscript and revised by author KOOS. All authors read and approved the final manuscript.

\section{Acknowledgements}

This authors appreciate Premier Medicaid International HMO, Ibadan Nigeria for providing financial (Grant No: 00001-03-014-PM) and technical assistance to execute the research. This research was also partially funded by the Consortium for Advanced Research Training in Africa (CARTA). CARTA is jointly led by the African Population and Health Research Center and the University of the Witwatersrand and funded by the Wellcome Trust (UK) (Grant No: 087547/Z/08/Z), the Department for International Development (DfID) under the Development Partnerships in Higher Education (DelPHE), the Carnegie Corporation of New York (Grant No: B 8606), the Ford Foundation (Grant No: 11000399), Google.Org (Grant No: 191994), SIDA (Grant No: 54100029) and MacArthur Foundation (Grant No: 10-95915-000-INP). The authors appreciate the assistance of Olajimi O. Latunji (Faculty of Public Health, University of Ibadan, Nigeria) for his technical inputs. Lastly, we thank all the participants that agreed to participate in this study.

\section{Conflict of Interest}

No competing interests exist.

\section{References}

1. Balaiah D, Ghule M, Naik DD, Parida RC and Hazari KT. Fertility attitudes and family planning practicies of men in a rural community of Maharashtra. J Fam Welf. 2001;47(1):56-67.

2. Aransiola JO, Akinyemi AI and Fatusi AO. Women's perceptions and reflections of male partners and couple dynamics in family planning adoption in selected urban slums in Nigeria:a qualitative exploration. BMC Public Health. 2014;1(14):869.

3. van Staveren I and Odebode O. Gender Norms as Asymmetric Institutions: A case Study of Yoruba Women in Nigeria. J Econ Issues. 2007;41(4):90325.

4. National Population Commission (NPC) [Nigeria] and ICF International. Nigeria Demographic and Health Survey 2013. Abuja Niger Rockville, Maryland, USA. 2014;

5. Oyediran KA, Ishola GP and Feyisetan BJ. Factors Affecting Ever-Married Men's contraceptive knowledge and use in Nigeria. $J$ Biosoc Sci [Internet]. 2002;34(4):497-510.

6. Wusu O. Interconnections among changing family structure, child rearing and fertility behaviour among the Ogu, Southwestern Nigeria: A qualitative study. Demogr Res. 2006;14:139-156.

7. Oladapo OT, Daniel OJ, Odusoga OL and AyoolaSotubo O. Fertility desires and intentions of HIVpositive patients at a suburban specialist center. $\mathbf{J}$ Natl Med Assoc. 2005;97(12):1672-81.

8. Sedgh G, Bankole A, Oye-Adeniran B, Adewole IF, Singh $S$ and Hussain R. Unwanted pregnancy and associated factors among Nigerian women. Int Fam Plan Perspect. 2006;32(4):175-84.

9. Sekoni OO and Owoaje ET. Male Knowledge of Danger Signs of Obstetric Complications in an Urban City in South West Nigeria. Ann Ibd Pg Med. 2014;12(2):89-95.

10. Jayalakshmi MS, Ambwani K, Prabhakar PK and Swain P. A study of male involvement in family planning. Heal Popul Perspect Issues. 2002;25(3):113-23.

11. Kura S, Vince J and Crouch-Chivers P. Male involvement in sexual and reproductive health in the Mendi district, Southern Highlands province of Papua New Guinea: a descriptive study. Reprod Health [Internet]. 2013;10(1):46.

12. Ohunakin OS, Adaramola MS, Oyewola OM and Fagbenle RO. Solar energy applications and development in Nigeria: Drivers and Barriers. Renew Sustain Energy Rev. 2014;32:294-301.

13. Oyo. The Official Website of Oyo State [Internet]. The Pacesetter State. 2014 [cited 2016 Mar 12]. Available from: http://www.oyostate.gov.ng/aboutoyo-state/

14. National Population Commission. Population Distribution By Sex, State, LGA \& Senatorial District. 2006 Population and Housing Census. 2006 Popul Hous Census [Internet]. 2010;III. Available from: http://www.population.gov.ng/images/Vol 03 Table DSx LGAPop by SDistrict-PDF.pdf 
15. NURHI. Rapid Ibadan: Urbanization, Population and the Opportunity for Ibadan to Develop; Building a Strong City with a High Quality of Life. 2013.

16. Iliyasu Z, Abubakar IS, Galadanci HS and Aliyu MH. Birth preparedness, Complication Readiness and Fathers' Participation in Maternity Care in a Northern Nigerian community. Afr J Reprod Health. 2010;14(1):21-32.

17. Jaiyeoba AO. Perceived impact of universal basic education on national development in Nigeria. Int $\mathbf{J}$ African African-American Stud. 2009;6(1).

18. Oyediran KA. Husband-wife communication and couple's fertility desires among the Yoruba of Nigeria. 2002;

19. Daniel MM, Wapwera SD, Akande EM, Musa CC and Aliyu AA. Slum Housing Conditions and Eradication Practices in Some Selected Nigerian Cities. J Sustain Dev [Internet]. 2015;8(2):230-41.

20. Oyeleye OI. Challenges of Urbanization and Urban Growth in Nigeria. Am J Sustain Cities Soc [Internet]. 2013;1(2):79-95.

21. Osili UO and Long BT. Does female schooling reduce fertility? Evidence from Nigeria. J Dev Econ. 2008;87(1):57-75.

22. Bongaarts J. The Implementation of preferences for Male Offspring. Popul Dev Rev. 2013;39(2):185-208.

23. Korra A and Haile M. Sexual behaviour and level of awareness on reproductive health among youths: Evidence from Harar, Eastern Ethiopia. Ethiop J Heal Dev. 1999;13(2):107-13.

24. Kabagenyi A, Jennings L, Reid A, Nalwadda G, Ntozi J and Atuyambe L. Barriers to male involvement in contraceptive uptake and reproductive health services: a qualitative study of men and women's perceptions in two rural districts in Uganda. Reprod Health [Internet]. 2014;11(1):21.

25. Tumlinson K, Speizer IS, Davis JT, Fotso JC, Kuria P and Archer LH. Partner communication, discordant fertility goals, and contraceptive use in urban Kenya. Afr J Reprod Health [Internet]. 2013;17(3):79-90.

26. White DR and Burton ML. Causes of polygyny: Ecology, economy, kinship, and warfare. Am Anthropol. 1988;90(4):871-87.

27. Izugbara $\mathrm{C}$, Ibisomi $\mathrm{L}$, Ezeh $\mathrm{AC}$ and Mandara $\mathrm{M}$. Gendered interests and poor spousal contraceptive communication in Islamic northern Nigeria. J Fam Plann Reprod Health Care. 2010;36(4):219-24.
28. Diro CW and Afework MF. Agreement and concordance between married couples regarding family planning utilization and fertility intention in Dukem, Ethiopia. BMC Public Health [Internet]. 2013;13(1):1-7.

29. Billari FC, Goisis A, Liefbroer AC, Settersten RA, Aassve A, Hagestad G and Speder Z. Social age deadlines for the childbearing of women and men. Hum Reprod. 2010 Mar;26(3):616-22.

30. Berrington A. Perpetual postponers? Women's, men's and couple's fertility intentions and subsequent fertility behaviour. Popul Trends. 2004;(117):9-19.

31. Dunson DB, Baird DD and Colombo B. Increased infert ility with age in men and women. Obstet Gynecol. 2004;103(1):51-6.

32. Ani F, Abiodun O, Sotunsa J, Faturoti O, Imaralu J and Olaleye A. Demographic factors related to male invlovement in reproductive health care services in Nigeria. Eur J Contracept Reprod Heal Care. 2016;21(1):57-67.

33. Dutta M and Kapilashrami MC, Tiwari VK. Knowledge, awareness and extent of male participation in key areas of reproductive and child health in an urban slum of Delhi. Heal Popul Perspect Issues. 2004;27(2):49-66.

34. Shahjahan M, Mumu SJ, Afroz A, Chowdhury HA, Kabir R and Ahmed K. Determinants of male participation in reproductive healthcare services: a cross-sectional study. Reprod Health. 2013;10(27):2-7.

35. Mahmood N and RIngheim K. Factors Affecting Contraceptive Use in Pakistan. Pak Dev Rev. 1996;35(1):1-22.

36. Baschieri A, Cleland J, Floyd S, Dube A, Msona A, Molesworth A, Glynn JR, French N. Reproductive Preferences and Contraceptive Use: a Comparison of Monogamous and Polygamous Couples in Northern Malawi. J Biosoc Sci [Internet]. 2013;45(2):145-66.

37. Mosha I, Ruben R and Kakoko D. Family planning decisions, perceptions and gender dynamics among couples in Mwanza, Tanzania: a qualitative study. BMC Public Health [Internet]. 2013;13(1):523.

38. Greene ME and Biddlecom AE. Absent and Problematic Men: Demographic Accounts of Male Reproductive Roles. Popul Dev Rev. 2000;26(1):81-115.

39. Federal Ministry of Health. Revised National Health Policy. Abuja; 2004. 